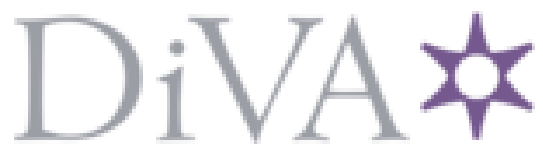

http://www.diva-portal.org

This is the published version of a paper published in Environmental Science and Technology.

Citation for the original published paper (version of record):

Bidleman, T F., Backus, S., Dove, A., Lohmann, R., Muir, D. et al. (2021)

Lake Superior Has Lost over 90\% of Its Pesticide HCH Load since 1986

Environmental Science and Technology, 55(14): 9518-9526

https://doi.org/10.1021/acs.est.oco7549

Access to the published version may require subscription.

N.B. When citing this work, cite the original published paper.

Permanent link to this version:

http://urn.kb.se/resolve?urn=urn:nbn:se:umu:diva-182215 


\title{
Lake Superior Has Lost over $90 \%$ of Its Pesticide HCH Load since 1986
}

\author{
Terry F. Bidleman,* Sean Backus, Alice Dove, Rainer Lohmann, Derek Muir, Camilla Teixeira, \\ and Liisa Jantunen
}

Cite This: Environ. Sci. Technol. 2021, 55, 9518-9526

Read Online

\section{ACCESS | Llll Metrics \& More | 国 Article Recommendations | (s) Supporting Information}

ABSTRACT: The time trend of $\alpha$ - and $\gamma$-hexachlorocyclohexane $(\mathrm{HCH})$ isomers in Lake Superior water was followed from 1986 to 2016, the longest record for any persistent organic pollutant (POP) in Great Lakes water. Dissipation of $\alpha-\mathrm{HCH}$ and $\gamma$-HCHs was first order, with halving times $\left(t_{1 / 2}\right)$ of 5.7 and $8.5 \mathrm{y}$, respectively. Loss rates were not significantly different starting a decade later (1996-2016). Concentrations of $\beta-\mathrm{HCH}$ were followed from 1996-2016 and dissipated more slowly $\left(t_{1 / 2}=16\right.$ y). In 1986, the lake contained an estimated 98.8 tonnes of $\alpha-\mathrm{HCH}$ and 13.2 tonnes of $\gamma-\mathrm{HCH}$; by 2016 , only $2.7 \%$ and $7.9 \%$ of 1986 quantities remained. Halving times of both isomers in water were longer than those reported in air, and for $\gamma-\mathrm{HCH}$, they were longer in water than those reported in lake trout. Microbial degradation

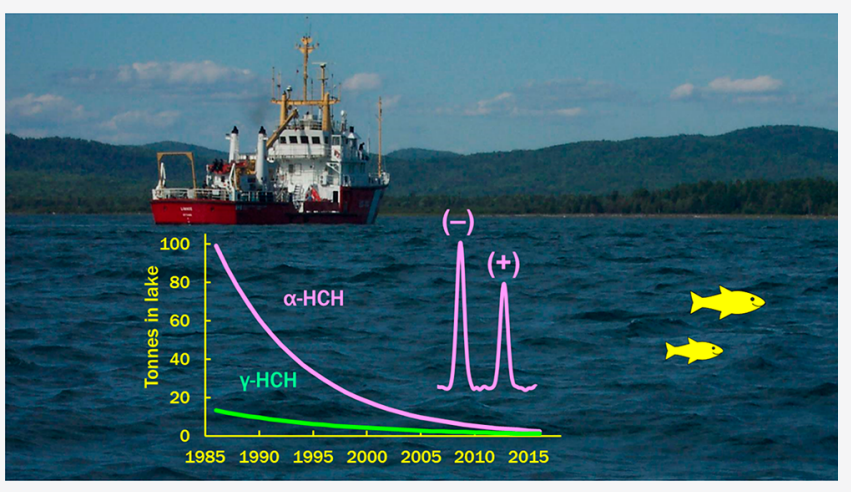
was evident by enantioselective depletion of $(+) \alpha-\mathrm{HCH}$, which increased from 1996 to 2011. Volatilization was the main removal process for both isomers, followed by degradation (hydrolytic and microbial) and outflow through the St. Mary's River. Sedimentation was minor. Major uncertainties in quantifying removal processes were in the two-film model for predicting volatilization and in microbial degradation rates. The study highlights the value of long-term monitoring of chemicals in water to interpreting removal processes and trends in biota.

\section{INTRODUCTION}

The five Laurentian Great Lakes bordering Canada and the United States have been recipients of persistent and toxic chemicals for many decades. Inputs came through direct discharge and runoff from the watersheds, but were often dominated by atmospheric deposition, especially for the larger lakes. ${ }^{1-3}$ The Great Lakes have responded rapidly to declines in atmospheric concentrations of persistent organic pollutants (POPs), such as polychlorinated biphenyls (PCBs) and organochlorine pesticides (OCPs), ${ }^{4-6}$ and burdens in fish have also decreased. ${ }^{7-9}$ Over time, the lakes have shifted from being net recipients to "secondary sources" of some POPs due to revolatilization from lake water. ${ }^{4,6}$ Since the early 1990s, The Canada-U.S. Integrated Atmospheric Deposition Network (IADN) and the Canadian Great Lakes Basin Monitoring and Surveillance Network (GLB) have monitored temporal trends of POPs and other chemicals of emerging concern in Great Lakes air and precipitation. Periodic reports have documented temporal trends in air concentrations, and atmospheric deposition/volatilization flows of toxic chemicals to and from the lakes. The most recent of these, which updates earlier reports, integrated a 20-year period from the early 1990s to 2012-2013 for air concentrations $s^{4,5}$ and up to 2012-2015 for atmospheric mass flows. ${ }^{4,6}$

Lake Superior (LS) is the largest of the Great Lakes: second in the world by area $\left(82100 \mathrm{~km}^{2}\right)$ and fourth by volume $\left(12100 \mathrm{~km}^{3}\right)$. LS is cold (mean temperature $5{ }^{\circ} \mathrm{C}$ ), and has an average water retention time of $191 \mathrm{y} \cdot{ }^{10}$ Atmospheric deposition and volatilization are major input and removal pathways for semivolatile chemicals. ${ }^{1}$ PCBs were lost from LS, mainly by volatilization, with a halving time $\left(t_{1 / 2}\right)$ of $3.5 \mathrm{y}$ between 1978 and 1992. ${ }^{11,12}$ The OCP toxaphene increased in the water column of LS from 1950 to the mid-1970s and then incurred net loss by volatilization through the 1990s.,13

Hexachlorocyclohexane $(\mathrm{HCH})$ is one of many OCPs found in Great Lakes water and air. Technical $\mathrm{HCH}$ products contain several isomers, of which $\alpha-\mathrm{HCH}$ is the most abundant, $\beta$ $\mathrm{HCH}$ is the most persistent and toxic, and $\gamma-\mathrm{HCH}$ is the only isomer with insecticidal activity. ${ }^{14-16}$ Technical HCH was discontinued in the U.S. and Canada in the 1970s and in some

Special Issue: POPs on the Global Scale: Sources, Distribution, Processes, and Lessons Learned for Chemicals Management

Received: November 8, 2020

Revised: March 23, 2021

Accepted: March 24, 2021

Published: April 7, 2021

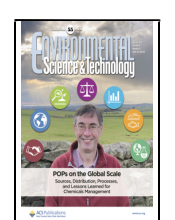


Asian countries during the 1980 s and early 1990 s, $^{15-17}$ but formulations of pure $\gamma-\mathrm{HCH}$ (lindane) continued to be used worldwide through the 1990s and into the first decade of this century. ${ }^{14,17-20}$ Lindane was deregistered for agricultural and veterinary uses in phase-outs between 2001 and 2005 in Canada and 1998 and 2009 in the U.S. ${ }^{21}$ Global production and usage of technical $\mathrm{HCH}$ and lindane were stopped in 2009 under the Stockholm Convention, with exceptions for some pharmaceutical uses of lindane. ${ }^{14}$ Technical $\mathrm{HCH}$ was the starting product for the manufacture of lindane, which resulted in an estimated 6 to 7 million tonnes of " $\mathrm{HCH}$ waste" (consisting mainly of $\alpha-\mathrm{HCH}, \beta-\mathrm{HCH}$, and $\delta$ - $\mathrm{HCH}$ ) produced and discarded or stored in poorly managed sites around the world. $^{14}$

$\mathrm{HCH}$ is the most abundant OCP in LS water, exceeding concentrations of toxaphene, ${ }^{3,13,22,23}$ chlordanes, DDTs, endosulfans, and dieldrin. ${ }^{24,25}$ Air concentrations of $\mathrm{HCHs}$ at Great Lakes monitoring stations have declined since the early 1990s, with halving times $\left(t_{1 / 2}\right)$ of about 4 to $5 \mathrm{y}$ and only slight differences between the $\alpha-\mathrm{HCH}$ and $\gamma-\mathrm{HCH}$ isomers and among the stations. ${ }^{5,6}$ Volatilization is a major loss process for $\mathrm{HCHs},{ }^{4}$ but it is unclear whether this is the only loss process. Variations in gas exchange direction and magnitude over time depend not only on the temporal trends in POPs atmospheric concentrations but also on their concentrations in lake water. ${ }^{4,6}$

In comparison to that of air, there has been less monitoring of POPs in Great Lakes water. Available data come from regular surveillance cruises and sporadic campaigns, but temporal trends in lake water are seldom reported. Lack of annual water concentration data limited the mass flow estimates for POPs in the Great Lakes. ${ }^{4}$ Here, we examine the time course of HCHs in LS water over 30 years (19862016) and evaluate processes which remove them from the lake. Our documentation is the longest period for any POP in Great Lakes water and provides an accurate record for interpreting time trends in biota.

\section{METHODS}

The upper water column ("surface" water, $\leq 12 \mathrm{~m}$ ) of LS was sampled for HCHs and other organic compounds in 11 years between 1986 and 2016. Collections were done mainly on spring (May, June) and summer (August) surveillance cruises which occupied the same stations each time, covered the nearshore and open lake areas (Supporting Information, Table SI-1.1, Figure SI-1.1), and occasionally included deep water $(>12-270 \mathrm{~m}) .^{24}$ The total number of surface measurements was 283 for $\alpha-\mathrm{HCH}, 257$ for $\gamma-\mathrm{HCH}$, and 103 for $\beta-\mathrm{HCH}$. Sampling methods varied. A submersible pump was used to take surface water onboard where it was stored in glass carboys or stainless steel cans. ${ }^{24-26}$ In some cases, water was collected in oceanographic bottles (e.g., Go-Flo) lined with polytetrafluoroethylene $^{24}$ or sampled passively in situ with low-density polyethylene (LDPE) film. ${ }^{27}$ Whole water samples were examined in 1986-1987, while in other years only the dissolved phase was analyzed after excluding the particulate fraction by centrifugation, filtration or passive sampling, and isolating the dissolved fraction using large volume liquid extraction (LVX), ${ }^{26}$ resin cartridges, ${ }^{24,25}$ or solvent extraction of passive samplers. ${ }^{27}$ An earlier study found that $\mathrm{HCH}$ sere dissolved and not detectable on glass fiber filters which preceded resin cartridges. ${ }^{28}$ The same paper estimated the particulate fraction, considering sorption to particles and association with dissolved/colloidal organic matter, and concluded that $99 \%$ of the HCHs were dissolved. Analytical methods used capillary gas chromatography with electron capture detection (ECD), quadrupole mass spectrometry in the electron capture negative ion mode (ECNI-MS), electron impact MS/MS or high-resolution mass spectrometry. Sampling, extraction and analytical methods are summarized in Table SI-1.1, and quality control measures are documented. ${ }^{24-27}$ The two enantiomers of the chiral compound $\alpha$ $\mathrm{HCH}$ were determined for water samples collected from 1996 to 1997 and in 2001, 2005, 2008, and 2011, using two GC columns with different chiral stationary phases which reversed the enantiomer elution order (SI-1). ${ }^{24}$

Table 1. Annual Geometric Mean $\mathrm{HCH}$ Concentrations $\left(\mathrm{ng} \mathrm{L}^{-1}\right)$ and EFs of $\alpha-\mathrm{HCH}$ in LS Surface Water ${ }^{a, b}$

$\begin{array}{ccccccc}\text { Years } & \begin{array}{c}\alpha- \\ \mathrm{HCH}\end{array} & \begin{array}{c}\beta- \\ \mathrm{HCH}\end{array} & \begin{array}{c}\gamma- \\ \mathrm{HCH}\end{array} & \begin{array}{c}\mathrm{EF} \text { of } \alpha- \\ \mathrm{HCH}\end{array} & \begin{array}{c}\gamma-\mathrm{HCH} / \alpha- \\ \mathrm{HCH}\end{array} & \begin{array}{c}\beta-\mathrm{HCH} / \alpha- \\ \mathrm{HCH}\end{array} \\ 2016 & 0.34 & 0.027 & 0.083 & & 0.24 & 0.079 \\ 2011 & 0.21 & 0.036 & 0.13 & 0.413 & 0.62 & 0.171 \\ 2008 & 0.75 & & 0.19 & 0.424 & 0.25 & \\ 2005 & 1.17 & 0.047 & 0.29 & 0.434 & 0.25 & 0.040 \\ 2002 & 1.13 & 0.042 & 0.30 & & 0.26 & 0.037 \\ 1998 & 1.38 & & 0.35 & & 0.25 & \\ 1997 & 2.52 & 0.078 & 0.45 & 0.438 & 0.25 & 0.043 \\ 1996 & 2.11 & 0.063 & 0.44 & & 0.17 & 0.025 \\ 1987 & 10.8 & & 0.39 & 0.450 & 0.18 & 0.027 \\ 1986 & 7.88 & & 1.01 & & 0.09 & \end{array}$

${ }^{a}$ Extended data in Table S1-1.1: collection/analytical methods, multiple samples within a year, arithmetic means, standard deviations, number of samples, and data sources. ${ }^{b}$ Isomer ratios calculated from annual geometric means.

\section{RESULTS AND DISCUSSION}

3.1. Concentrations and Proportions of $\mathrm{HCH}$ Isomers and $\boldsymbol{\alpha}-\mathrm{HCH}$ Enantiomers in LS Water. Table 1 reports annual geometric mean (GM) concentrations of $\alpha-\mathrm{HCH}, \beta$ $\mathrm{HCH}$, and $\gamma-\mathrm{HCH}$ in LS surface water. An expanded data table which includes results of multiple samplings within a year, arithmetic annual means, standard deviations, sample numbers, and collection/analysis methods is provided in Table SI-1.1. The decreasing trend in annual GM $\alpha-\mathrm{HCH}$ and $\gamma-\mathrm{HCH}$ concentrations over the 30 -year period is shown in Figure 1. Depth profiles were taken from the surface to $250-270 \mathrm{~m}$ in August 1996 and August 2005 and there was no significant trend with depth for either isomer (Figure 2). LS is dimictic and appears to be well mixed with respect to $\mathrm{HCHs}$, at least to these depths.

Isomer proportions in lake water changed over the study period (Table 1). The ratio of annual GM $\gamma-\mathrm{HCH} / \alpha-\mathrm{HCH}$ concentrations rose from 0.09 to 0.14 in the $1980 \mathrm{~s}$ to 0.25 in 1998 and remained between 0.24 and 0.26 through 2016, with one aberrant value of 0.62 in 2011 . The $\beta-\mathrm{HCH} / \alpha-\mathrm{HCH}$ ratio also increased since it was first measured in 1996, probably reflecting the greater environmental stability of $\beta-\mathrm{HCH},{ }^{16}$ and lower Henry's law constant ${ }^{29}$ which disfavors volatilization. The increasing $\gamma-\mathrm{HCH} / \alpha-\mathrm{HCH}$ ratio fits with the historical shift in $\mathrm{HCH}$ product usage from technical $\mathrm{HCH}$, containing $55-80 \% \alpha-\mathrm{HCH}, 8-15 \% \gamma-\mathrm{HCH}, 5-14 \% \beta-\mathrm{HCH}$, and other isomers to formulations of lindane $(\gamma-\mathrm{HCH}) .^{16,18}$ Technical 

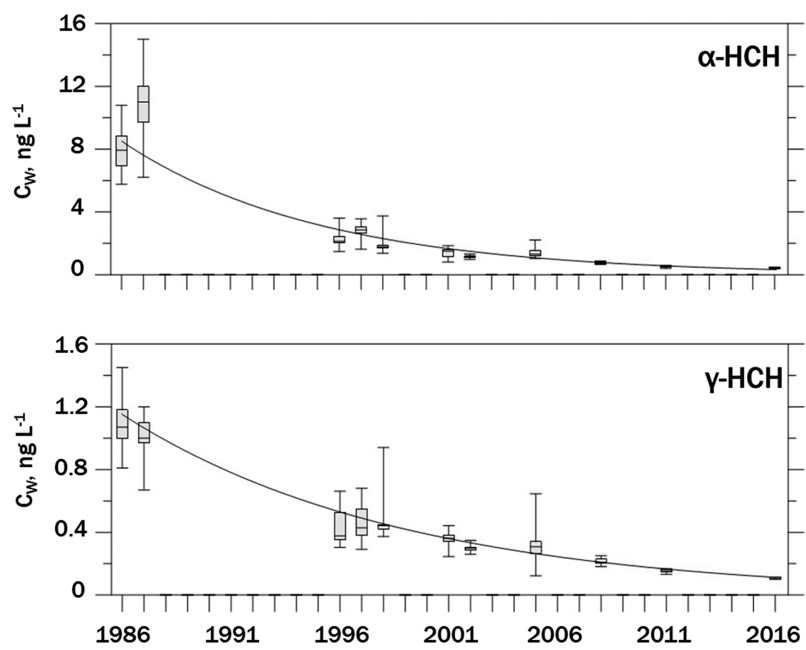

Figure 1. Decline in $\alpha-\mathrm{HCH}$ (top) and $\gamma-\mathrm{HCH}$ (bottom) concentrations in LS water from 1986 to 2016. Whiskers show ranges of concentrations, boxes show quartiles with median as a horizontal line. Data are summarized in Table SI-1.1. Time trends are also displayed in Figure 3, Figure SI-1.2 and Figure SI-1.3.

$\mathrm{HCH}$ was discontinued in Canada in 1971 and the U.S. in $1978{ }^{16}$ and lindane was used in both countries until registrations for agricultural and veterinary applications were canceled in 2004 and 2009..$^{21}$

Passive air samplers were deployed across North America in 2000-2001 to determine the continent-wide distribution of $\mathrm{HCH}$ in the atmosphere. ${ }^{30}$ Ratios of $\gamma-\mathrm{HCH} / \alpha-\mathrm{HCH}$ varied from $0.07-5$, with a continental average of 1.0. Regions with lower ratios, Atlantic and Pacific coasts of Canada, eastern Canadian Arctic, and Canadian mountains, were likely influenced by long-range transport from outside North America and in coastal areas to revolatilization of $\alpha-\mathrm{HCH}$ from seawater. Higher ratios were found in the Canadian prairies, the eastern U.S.A., and Mexico, which were more influenced by lindane usage. Compared to those of the latter group, ratios near the Great Lakes were slightly lower and were attributed to preferential of volatilization $\alpha-\mathrm{HCH}$ from Great Lakes water. ${ }^{30}$

The enantiomer fraction (EF) was calculated from concentrations of the $(+)$ and $(-)$ enantiomers. ${ }^{31}$

$$
\mathrm{EF}=\frac{(+) \alpha-\mathrm{HCH}}{[(+) \alpha-\mathrm{HCH}+(-) \alpha-\mathrm{HCH}]}
$$

Mean EFs in surface water ranged from $0.450 \pm 0.005$ in 1996 to $0.413 \pm 0.002$ in 2011 (Table 1) and decreased linearly over 15 years with $r^{2}=0.94$ (Figure SI-1.4). Decreasing EFs indicate greater microbial degradation of (+) $\alpha-\mathrm{HCH}$ over time. Depth profiles taken in August 2005 (Figure SI-1.4) show no variation in EF with depth which is strikingly different from the strongly decreasing gradient in EFs observed for the stratified Arctic Ocean,,$^{32-36}$ and those together with invariant $\alpha-\mathrm{HCH}$ concentrations with depth (Figure 2) indicate a well-mixed lake. Revolatilization of microbially degraded $\alpha-\mathrm{HCH}$ that was depleted in the (+) enantiomer lowered EFs in air over and near the Great Lakes, ${ }^{24,30,37}$ the Atlantic coast of Canada, ${ }^{30}$ and the eastern Canadian Arctic. ${ }^{30,34,35,38}$

3.2. Time Trends of $\mathrm{HCHs}$ in Water, Air and Fish. Dissipation of $\mathrm{HCH}$ from LS by all processes ( $\mathrm{F}_{\mathrm{LOSS}}, \mathrm{kg} \mathrm{y}^{-1}$ ) was followed by plotting the natural logarithm of annual GM water concentrations $\left(\mathrm{C}_{\mathrm{W}}, \mathrm{ng} \mathrm{L^{-1 }}\right)$ vs year (Table 1, Figure 3 ).

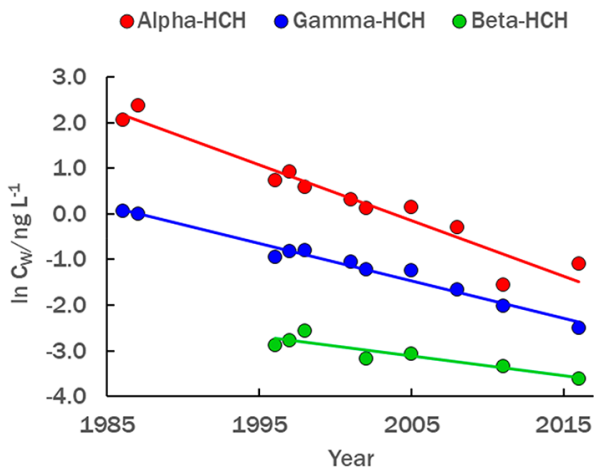

Figure 3. First-order decline in annual geometric mean concentrations of $\alpha-\mathrm{HCH}, \beta-\mathrm{HCH}$, and $\gamma-\mathrm{HCH}$; regression equations: $\ln C_{\mathrm{W}}$ $(\alpha-\mathrm{HCH})=244.3918-0.122 *$ year; $\ln C_{\mathrm{W}}(\beta-\mathrm{HCH})=82.279-$ $0.0426 *$ year; $\ln C_{\mathrm{W}}(\gamma-\mathrm{HCH})=162.8215-0.08194 *$ year. Regressions for arithmetic means and all data points are shown in Figures SI-1.2 and SI-1.3.

Similar plots using annual arithmetic mean (AM) concentrations and all concentration points for all years are shown in Figures SI-1.2 and SI-1.3. Table 2 presents first-order dissipation rate constants $\left(\mathrm{k}_{\mathrm{DISS}}, \mathrm{y}^{-1}\right)$, halving times $\left(t_{1 / 2}, \mathrm{y}=\right.$
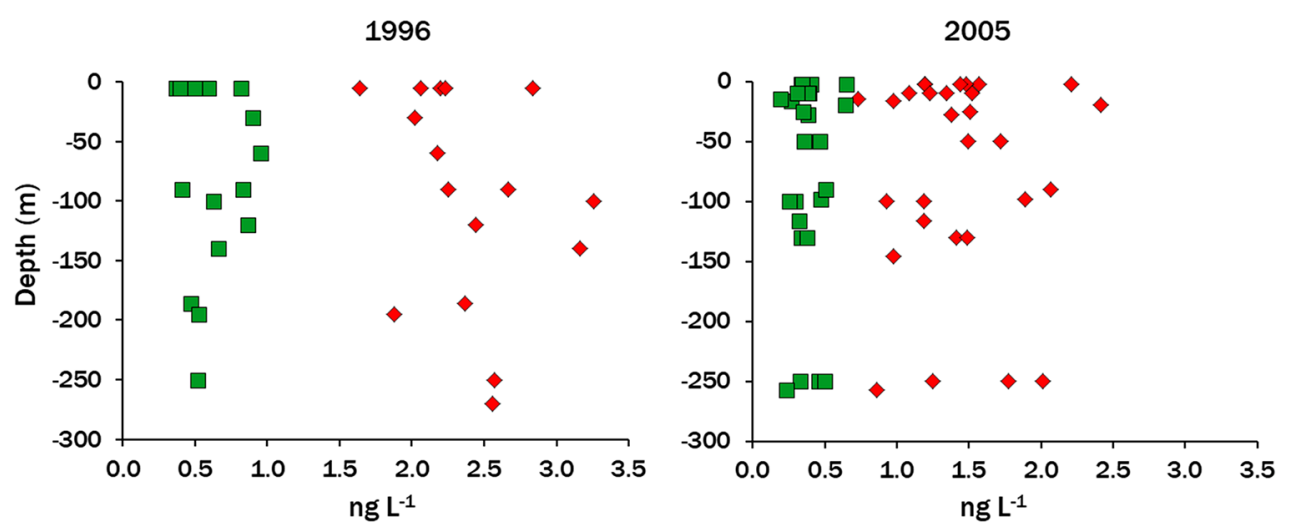

Figure 2. Depth profiles of $\alpha$-HCH (red diamonds) and $\gamma$-HCH (green squares) in LS, August 1996 and August 2005. There are no significant depth trends for either isomer $(p>0.05)$. 
Table 2. Dissipation Rate Constants $\left(\mathrm{k}_{\mathrm{DISS}}\right)$ and Halving Times $\left(t_{1 / 2}\right)$ of HCHs in Lake Superior Water ${ }^{a}$

\begin{tabular}{|c|c|c|c|c|c|c|c|c|c|c|c|c|c|c|}
\hline \multirow[b]{2}{*}{ Regression method ${ }^{b}$} & \multirow[b]{2}{*}{$\mathrm{r}^{2}$} & \multirow[b]{2}{*}{$\mathrm{k}_{\text {DISS, }} \mathrm{y}^{-1}$} & \multicolumn{3}{|c|}{ Water 1,1986 to 2016} & \multirow[b]{2}{*}{$-95 \% \mathrm{Cl}$} & \multirow[b]{2}{*}{$+95 \% \mathrm{Cl}$} & \multirow[b]{2}{*}{$r^{2}$} & \multirow[b]{2}{*}{$\mathrm{k}_{\mathrm{DISS},} \mathrm{y}^{-1}$} & \multicolumn{3}{|c|}{ Water 2, 1996 to 2016} & \multirow[b]{2}{*}{$-95 \% \mathrm{Cl}$} & \multirow[b]{2}{*}{$+95 \% \mathrm{Cl}$} \\
\hline & & & $-95 \% \mathrm{Cl}$ & $+95 \% \mathrm{Cl}$ & $t_{1 / 2}, y$ & & & & & $-95 \% \mathrm{Cl}$ & $+95 \% \mathrm{Cl}$ & $\mathrm{t}_{1 / 2}, \mathrm{y}$ & & \\
\hline \multicolumn{15}{|l|}{$\underline{\alpha-\mathrm{HCH}}$} \\
\hline $\mathrm{AM}$ & 0.95 & 0.116 & 0.136 & 0.0970 & 5.96 & 5.11 & 7.15 & 0.91 & 0.105 & 0.134 & 0.0761 & 6.61 & 5.19 & 9.11 \\
\hline GM & 0.93 & 0.122 & 0.147 & 0.0968 & 5.68 & 4.71 & 7.16 & 0.86 & 0.113 & 0.155 & 0.0717 & 6.11 & 4.47 & 9.67 \\
\hline All & 0.73 & 0.130 & 0.140 & 0.121 & 5.32 & 4.97 & 5.73 & 0.57 & 0.130 & 0.145 & 0.116 & 5.31 & 4.79 & 5.97 \\
\hline \multicolumn{15}{|l|}{$\beta-\mathrm{HCH}$} \\
\hline $\mathrm{AM}$ & & & & & & & & 0.77 & 0.0393 & 0.0640 & 0.0146 & 17.6 & 10.8 & 47.5 \\
\hline GM & & & & & & & & 0.83 & 0.0426 & 0.0650 & 0.0201 & 16.3 & 10.7 & 34.4 \\
\hline All & & & & & & & & 0.28 & 0.0205 & 0.0269 & 0.0141 & 33.8 & 25.7 & 49.3 \\
\hline \multicolumn{15}{|l|}{$\chi-\mathrm{HCH}$} \\
\hline $\mathrm{AM}$ & 0.97 & 0.0795 & 0.0896 & 0.0694 & 8.72 & 7.73 & 9.98 & 0.94 & 0.0798 & 0.0980 & 0.0616 & 8.69 & 7.07 & 11.3 \\
\hline GM & 0.98 & 0.0819 & 0.0918 & 0.0721 & 8.46 & 7.55 & 9.62 & 9.95 & 0.0833 & 0.101 & 0.0655 & 8.32 & 6.86 & 10.6 \\
\hline All & 0.75 & 0.0771 & 0.0826 & 0.0716 & 8.99 & 8.39 & 9.68 & 0.57 & 0.0748 & 0.0835 & 0.0661 & 9.27 & 8.30 & 10.5 \\
\hline
\end{tabular}

${ }^{a} \mathrm{k}_{\mathrm{DISS}}=$ slope of $\ln \mathrm{C}_{\mathrm{w}} / \mathrm{ng} \mathrm{L^{-1 }}$ vs year, $t_{1 / 2}=0.693 / \mathrm{k}_{\mathrm{DISS}}{ }^{b}$ Regression of natural logarithms of $\mathrm{C}_{\mathrm{w}} / \mathrm{ng} \mathrm{L}^{-1}: \mathrm{AM}=$ annual arithmetic means, GM $=$ annual geometric means, All = all data points.

$\left.0.693 / \mathrm{k}_{\mathrm{DISS}}\right)$, and $95 \%$ confidence intervals $(\mathrm{CI}= \pm$ $\left.\mathrm{t}_{0.05, \mathrm{n}-2)}{ }^{\mathrm{S}} \mathrm{SE}\right)$, where SE is the standard error of $\mathrm{k}_{\mathrm{DISS}}{ }^{5}$ The $t_{1 / 2}$ values $( \pm 95 \% \mathrm{CI})$ derived from GM regression in the time series $1986-2016$ (Water 1 ) were $\alpha-\mathrm{HCH} 5.68$ y (4.71-7.16 y) and $\gamma-\mathrm{HCH} 8.46$ y (7.55-9.62 y). Faster loss was found for 25 PCB congeners between 1980 and 1992, with $t_{1 / 2}=3.5 \mathrm{y}^{12}$

The gap between 1986 and 1987 and later measurements prompted us to examine the shorter series from 1996 to 2016 (Water 2). Regressions of $\beta$ - HCH from 1996 to 2016 were included in this set. The $t_{1 / 2}$ values $( \pm 95 \% \mathrm{CI})$, derived from GM regressions for Water 2, were $\alpha-\mathrm{HCH} 6.11$ y $(4.47-9.67$ y), $\beta$-HCH 16.3 y (10.7-34.4 y), and $\gamma$ - $\mathrm{HCH} 8.32$ y (6.86$10.6 \mathrm{y})$. The $95 \% \mathrm{CIs}$ for Water 1 and Water 2 overlapped, indicating similar $t_{1 / 2}$ in the longer and shorter time series. The slower dissipation of $\beta$ - $\mathrm{HCH}$ reflects its greater environmental persistence. $^{15,16}$

Halving times of gas-phase HCHs in air at Eagle Harbor, LS, derived from annual GM concentrations monitored from 1991 to 2013 (Air $1, \mathrm{n}=19$ ), were $4.29 \pm 0.16$ y for $\alpha-\mathrm{HCH}$ and $4.55 \pm 0.25$ y for $\gamma-\mathrm{HCH}{ }^{5}$ and the $95 \%$ CI were $3.95-4.63 \mathrm{y}$ and 4.03-5.07 y. Similar statistics for a shorter time interval (Air 2, 1999-2010, $\mathrm{n}=12$ ) were $\alpha-\mathrm{HCH}: 3.92 \pm 0.32$ y $(3.22-4.62 \mathrm{y})$ and $\gamma-\mathrm{HCH}: 3.09 \pm 0.22 \mathrm{y}(2.61-3.57 \mathrm{y}) .^{9}$ The 95\% CI for both isomers in Air 1 were shorter than, and did not overlap, the 95\% CI for Water 1 (Table 2), indicating slower dissipation in lake water. There was overlap of the $95 \%$ CI for $\alpha-\mathrm{HCH}$, but not $\gamma-\mathrm{HCH}$, in Water 2 and Air 2 .

$\mathrm{HCHs}$ in Superior lake trout (Salvelinus namaycush) declined from 1999 to 2010 , with $t_{1 / 2} 4.90 \pm 0.83$ y (95\% CI $3.05-6.75$ y) for $\alpha-\mathrm{HCH}(\mathrm{n}=12)$ and $3.23 \pm 0.92$ y $(95 \%$ CI $0.98-5.48 \mathrm{y})$ for $\gamma-\mathrm{HCH}(\mathrm{n}=8) .{ }^{9}$ The central $t_{1 / 2}$ of both isomers are shorter for fish than those for Water 2 (1996 to 2016). The 95\% CIs for fish and Water 2 overlap for $\alpha-\mathrm{HCH}$ but not $\gamma-\mathrm{HCH}$.

Monitoring data for lake trout, collected from the five Great Lakes during 1970s and 1980s and 2003, showed long-term declines in PCBs, polybrominated diphenyl ethers (PBDEs) and several OCPs (DDT compounds, dieldrin, chlordane compounds, and toxaphene), but rates of decline varied according to the compound, lake, and period of time over which $\mathrm{k}_{\text {DISS }}$ was calculated. ${ }^{7}$ In general, rates derived from 1970s and 1980s data were faster than those derived from monitoring in the 1980s and 2003, and some compounds showed net accumulation in the early time period. The authors stated that "As concentrations in fish reflect concentrations in water, the change in source functions could be the primary factor behind rate changes observed in fish." Such changes were judged a more likely explanation for the observed rate changes, rather than changes in climate, food webs, or fisheries dynamics. Long-term data series for LS which spanned about 40 years for fish and 25 years for air showed close coupling of the decline rates in fish and air for PCBs and DDTs. ${ }^{8}$

The loss budgets of $\alpha-\mathrm{HCH}$ and $\gamma-\mathrm{HCH}$, calculated from GM concentrations, are reported in SI-2.1, Tables SI-2.1a,b. In 1986, LS contained $98700 \mathrm{~kg}$ of $\alpha-\mathrm{HCH}$ and $13200 \mathrm{~kg}$ of $\gamma$ $\mathrm{HCH}$, and between 1986 and 2016, it contained $90400 \mathrm{~kg}$ of $\alpha-\mathrm{HCH}$ and $12200 \mathrm{~kg}$ of $\gamma-\mathrm{HCH}$ were dissipated (Table SI$2.1 \mathrm{a}, \mathrm{b})$. By the end of 2016, quantities of these two isomers remaining in the lake were only $2.7 \%$ and $7.9 \%$ of those in 1986.

Under the Canadian Environmental Protection Act, ${ }^{39}$ "Virtual Elimination is the ultimate reduction of the quantity or concentration of a toxic substance in the release into the environment below concentrations that can be accurately measured or the "level of quantification". A similar concept defines "temporal environmental hysteresis" as the "time lag between when a pollutant's input to the environment stops and when its concentration in the environment drops to some desired fraction of its maximum concentration." 40

The level of quantification (LOQ) is the lowest concentration of the toxic substance that can be accurately measured using sensitive but routine sampling and analytical methods." 39 Field blanks based on resin cartridge sampling of $80-100 \mathrm{~L}$ were $0.001 \mathrm{ng} \mathrm{L}^{-1}$ or lower (Table SI-1.1). With taking the LOQ as 10 times this level $\left(0.01 \mathrm{ng} \mathrm{L}^{-1}\right)$ and using the regression equations in Figure 3, extrapolated years of virtual elimination for the three HCHs in LS are 2040-2043.

3.3. HCH Removal Processes. $\mathrm{F}_{\mathrm{LOSS}}$ is the net loss. $\mathrm{HCHs}$ have been continuously entering the lake at a declining rate, mainly by atmospheric deposition (gas exchange and precipitation). Atmospheric deposition of $\alpha-\mathrm{HCH}$ exceeded volatilization until the mid-1990s; volatilization dominated through the 2000s, and between 2010 and 2015, the two flows were nearly even. ${ }^{4}$ The picture was similar for $\gamma$ - $\mathrm{HCH}$ with different timing. Deposition exceeded volatilization through the early 2000s, after which volatilization became dominant and remained so through 2015 . 
$\mathrm{F}_{\mathrm{LOSS}}$ is the sum of several loss processes: volatilization $\left(\mathrm{F}_{\mathrm{VOL}}\right)$, outflow through the St. Mary's River ( $\left.\mathrm{F}_{\mathrm{OUT}}\right)$, sedimentation $\left(\mathrm{F}_{\mathrm{SED}}\right)$, and degradation due to basic hydrolysis $\left(\mathrm{F}_{\mathrm{HYD}}\right)$ and microbial breakdown $\left(\mathrm{F}_{\mathrm{MIC}}\right)$.

$$
\mathrm{F}_{\mathrm{LOSS}}=\mathrm{F}_{\mathrm{VOL}}+\mathrm{F}_{\mathrm{OUT}}+\mathrm{F}_{\mathrm{SED}}+\mathrm{F}_{\mathrm{HYD}}+\mathrm{F}_{\mathrm{MIC}}
$$

These dissipation processes are summarized below and in SI-2. The quantities of $\alpha-\mathrm{HCH}$ and $\gamma-\mathrm{HCH}$ in the lake at the beginning of each year were subjected to the individual loss processes (eq 2), and their sum was compared to the directly determined $\mathrm{F}_{\mathrm{LOSS}}$. The rate constants for $\mathrm{F}_{\mathrm{VOL}}, \mathrm{F}_{\mathrm{HYD}}$, and $\mathrm{F}_{\mathrm{MIC}}$ were applied to the annually declining $\mathrm{GM} \mathrm{C} \mathrm{C}_{\mathrm{W}}$ (Figure 3). $\mathrm{F}_{\mathrm{OUT}}$ and $\mathrm{F}_{\mathrm{SED}}$ were calculated differently, as described below.

3.3.1. Volatilization. We calculated $\mathrm{F}_{\mathrm{VOL}}$ from the Whitman two-film gas exchange model in the form ${ }^{4}$

$$
\mathrm{F}_{\mathrm{VOL}}=\mathrm{A} \times \mathrm{C}_{\mathrm{W}} \times \mathrm{K}_{\mathrm{OL}}
$$

where $A$ is the area of $\operatorname{LS}\left(8.21 \times 10^{10} \mathrm{~m}^{2}\right), \mathrm{C}_{\mathrm{W}}\left(\mathrm{kg} \mathrm{m}^{-3}\right)$ is the concentration in surface water, and $\mathrm{K}_{\mathrm{OL}}\left(\mathrm{m} \mathrm{y}^{-1}\right)$ is the annually averaged overall mass transfer coefficient, considered from the water side, which includes resistances to transfer in the water and air phases. ${ }^{4,41}$ Details are provided in SI-2.2 and Table SI2.3. We used the smoothed record of annual GM concentrations in surface water from 1986 to 2016 (Figure 3, Table 1, Table SI-2.2) and assumed thermodynamically consistent "final adjusted values" (FAVs) for the Henry's law constants of the HCHs. ${ }^{29} \mathrm{~K}_{\mathrm{OL}}$ values were calculated at the high and low excursions of annual water temperature (273$293 \mathrm{~K})$ and wind speed $\left(4-8 \mathrm{~m} \mathrm{~s}^{-1}\right)$, taking these excursions from Figure S2 in the Supporting Information of Guo et al. ${ }^{4}$ $\mathrm{K}_{\mathrm{OL}}$ ranged from 4.8 to $44 \mathrm{~m} \mathrm{y}^{-1}\left(\mathrm{GM} 14 \mathrm{~m} \mathrm{y}^{-1}\right)$ for $\alpha-\mathrm{HCH}$ and 2.0 to $19 \mathrm{~m} \mathrm{y}^{-1}$ (GM $6.1 \mathrm{~m} \mathrm{y}^{-1}$ ) for $\gamma$-HCH (Table SI2.3). GM K $\mathrm{K}_{\mathrm{OL}}$ were used to calculate annual $\mathrm{F}_{\mathrm{VOL}}$, which for $\alpha$ $\mathrm{HCH}$ ranged from $9580 \mathrm{~kg} \mathrm{y}^{-1}$ in 1986 to $247 \mathrm{~kg} \mathrm{y}^{-1}$ in 2016 and totaled $81600 \mathrm{~kg}$ over 30 years (Table SI-2.1a). The total quantity of $\gamma-\mathrm{HCH}$ removed by volatilization ranged from 548 $\mathrm{kg}$ in 1986 to $47 \mathrm{~kg}$ in 2016 and totaled $6420 \mathrm{~kg}$ over 30 years. (Table SI-2.1b). These quantities are $90 \%$ and $53 \%$ of total measured $\mathrm{F}_{\text {LOSS. }}$.

3.3.2. Outflow. Outflow of HCHs from LS to Lake Huron takes place through the St. Mary's River. Rather than using a single process parameter for outflow, annual smoothed $\mathrm{HCH}$ concentrations (Figure 3) were multiplied by annually averaged river discharge (Table SI-2.4) to obtain $\mathrm{F}_{\text {OUT }}$. Outflow removed $4570 \mathrm{~kg}$ of $\alpha-\mathrm{HCH}$ and $830 \mathrm{~kg}$ of $\gamma-\mathrm{HCH}$ between 1986 and 2016, 5.1\% and $6.8 \%$ of total measured $\mathrm{F}_{\text {LOSS }}$ (SI-2.3, Table SI-2.1a,b).

3.3.3. Sedimentation. Few measurements were found for $\mathrm{HCH}$ in LS sediments. We combined sediment concentration data from Jackfish Bay, averaged from 1986 and 1998 (SI-2.5, Table SI-2.5), with a high-end sedimentation accumulation rate $\left(1 \mathrm{~g} \mathrm{~m}^{-2} \mathrm{~d}^{-1}\right)$ (Table SI-2.5) to estimate $\mathrm{F}_{\mathrm{SED}}$ of 2.6 and $2.1 \mathrm{~kg} \mathrm{y}^{-1}$ for $\alpha$-HCH and $\gamma-\mathrm{HCH}$. Sediment accumulation of $\mathrm{HCH}$ is a small term. Assuming the same $\mathrm{F}_{\mathrm{SED}}$ each year, total removal over 30 years was $78 \mathrm{~kg}$ of $\alpha-\mathrm{HCH}$ and $63 \mathrm{~kg}$ of $\gamma$ $\mathrm{HCH}$. Even though sedimentation of $\mathrm{HCHs}$ is probably low, the sediments could participate in the geochemical cycling. For example, particle settling brings PCBs and other hydrophobic organic contaminants to the bottom of LS, but very little of this material is accumulated in the sediments. Instead, these compounds are efficiently "recycled" within the benthic nepheloid layer (BNL) by decomposition of the settling particulate organic matter and/or surficial sediments. ${ }^{42-45}$ If
BNL recycling also occurs for $\mathrm{HCHs}$, microbial processes in this layer might contribute to the enantioselective degradation of $\alpha-\mathrm{HCH}$ observed in surface and deep water (Section 3.3.5).

3.3.4. Hydrolysis. The $\alpha-\mathrm{HCH}$ and $\gamma-\mathrm{HCH}$ isomers are subject to basic hydrolysis in the slightly alkaline $(\mathrm{pH} 7.83)$ water of LS (SI-2.5), whereas $\beta$-HCH is stable. We used the temperature-dependent second-order basic hydrolysis rate constants $\left(\mathrm{k}_{\mathrm{B}}, \mathrm{M}^{-1} \mathrm{y}^{-1}\right)$ of Ngabe et al. ${ }^{46}$ to derive the pseudo first-order rate constants $\left(\mathrm{k}_{\alpha}^{\prime}=0.0177 \mathrm{y}^{-1} ; \mathrm{k}_{\gamma}^{\prime}=0.0109 \mathrm{y}^{-1}\right)$ at $\mathrm{pH} 7.83$ and $5{ }^{\circ} \mathrm{C}$ (SI-2.6, Table SI-2.6). Hydrolysis is a substantial portion $(14-16 \%)$ of total measured $\mathrm{F}_{\text {LOSS }}$, accounting for 30-year removal of $14750 \mathrm{~kg}$ of $\alpha-\mathrm{HCH}$ and $1670 \mathrm{~kg}$ of $\gamma$-HCH (Tables SI-2.1a,b)

3.3.5. Microbial degradation. Aerobic microbial degradation of $\mathrm{HCHs}$ is common in soils, freshwater, groundwater, and seawater. ${ }^{24,32-38,47-49}$ Pathways for bacterial degradation of anthropogenic contaminants in soils have been extensively studied and involve several genera of Sphingomonad bacteria belonging to the class Alphaproteobacteria and family Sphingomonadaceae $e^{49-53}$ as well as other degraders such as Pseudomonas spp. ${ }^{51,54,55}$ "Lin" enzymes in these bacteria catalyze degradation of HCHs. The initial conversion of $\alpha$ $\mathrm{HCH}$ and $\gamma-\mathrm{HCH}$ to pentachlorocyclohexenes involves dehydrochlorinase $\operatorname{LinA}^{49,51,56,57}$ Enzyme LinB catalyzes degradation of $\alpha-\mathrm{HCH}, \beta-\mathrm{HCH}$, and $\delta-\mathrm{HCH}$ to pentachlorocyclohexanols as a first step. ${ }^{50,53,56}$ LinA has two variants, LinA1 and LinA2, which dehydrochlorinate either the $(+) \alpha-$ $\mathrm{HCH}$ or $(-) \alpha-\mathrm{HCH}$ enantiomer, respectively. ${ }^{50-52,56,58}$ Enantioselective fractionation of the two $\alpha-\mathrm{HCH}$ enantiomers can be due to changes in the relative abundance and reactivity of LinA1 and LinA2 during bacterial growth. ${ }^{51,52}$

EFs of $\alpha-\mathrm{HCH}$ in soil and water vary greatly according to selective degradation of either the $(+)$ enantiomer $(\mathrm{EF}<0.5)$ or the $(-)$ enantiomer $(\mathrm{EF}>0.5)$ (eq 1). ${ }^{59,60}$ It has been noted that enantioselective degradation of $(+) \alpha-\mathrm{HCH}$ in fresh water tends to be favored in cold, oligotrophic systems, such as the Great Lakes and Arctic lakes, and less so in temperate lakes and wetlands. ${ }^{47}$ These findings led to the hypothesis that enantioselective degradation is optimized in nutrient-poor waters in which oligotrophic bacteria may act as biofilms. ${ }^{47}$ PCBs and other hydrophobic organic contaminants on settling particles are recycled within the BNL of LS by decomposition of the labile organic matter (Section 3.3.3). ${ }^{42,44,45}$ This may also provide an active environment for enantioselective degradation of $\alpha-\mathrm{HCH}$ and other chiral compounds.

EFs of $\alpha-\mathrm{HCH}$ in Lake Superior surface water declined linearly from 0.450 in 1996 to 0.413 in $2011\left(\mathrm{r}^{2}=0.94\right)$, and in 2005, the EFs did not vary with depth (Table 1, Figure SI-1.4). From these results, the ratio of pseudo first-order microbial degradation rate constants was $k_{\mathrm{m}+} / k_{\mathrm{m}-}=1.33$ (Table SI-2.7). It is not possible to derive absolute rate constants from this ratio and the decline of total $\alpha-\mathrm{HCH}$ (sum of enantiomers) because $\mathrm{F}_{\mathrm{LOSS}}$ involves processes in addition to degradation.

Pseudo first-order microbial degradation rate constants $\left(k_{\mathrm{m}}\right.$, $\left.\mathrm{y}^{-1}\right)$ for HCHs were reported in the Bering Sea-Eastern Arctic Ocean; $k_{\mathrm{m}}=0.037 \mathrm{y}^{-1}$ for $\gamma-\mathrm{HCH}, k_{\mathrm{m}+}=0.117$ and $k_{\mathrm{m}-}=$ $0.030 \mathrm{y}^{-1}$ for $\alpha$-HCH enantiomers, and $k_{\mathrm{m}}=0.117+0.030=$ $0.147 \mathrm{y}^{-1}$ for total $\alpha-\mathrm{HCH}$ (sum of enantiomers). ${ }^{32,33} \mathrm{~F}_{\mathrm{MIC}}$ for $\gamma-\mathrm{HCH}$ in LS was estimated using the Harner et al. ${ }^{32,33}$ rate constant, $k_{\mathrm{m}}=0.037 \mathrm{y}^{-1}$, which resulted in loss of $5620 \mathrm{~kg}$ over 30 years (Table SI-2.1b).

Two sets of microbial degradation estimates were made for $\alpha$ - $\mathrm{HCH}$ in LS. $\mathrm{F}_{\mathrm{MIC} 1}$ was predicted using $k_{\mathrm{m}}=0.147 \mathrm{y}^{-1}$ for 
total $\alpha$-HCH. ${ }^{32,33} \mathrm{~F}_{\mathrm{MIC} 2}$ used $k_{\mathrm{m}-}=0.030 \mathrm{y}^{-1}$ and estimated $k_{\mathrm{m}+}=0.040 \mathrm{y}^{-1}$, based on our observed ratio of $k_{\mathrm{m}+} / k_{\mathrm{m}-}=1.33$ in LS. Thus, $k_{\mathrm{m}}$ for total $\alpha-\mathrm{HCH}=k_{\mathrm{m}+}+k_{\mathrm{m}-}=0.070 \mathrm{y}^{-1}(\mathrm{SI}-2$, Figure SI-1.2, Table SI-1.4). Microbial degradation of $\alpha-\mathrm{HCH}$ over 30 years totaled $115000 \mathrm{~kg}\left(\mathrm{~F}_{\mathrm{MIC1}}\right)$ or $56800 \mathrm{~kg}\left(\mathrm{~F}_{\mathrm{MIC} 2}\right)$ (Table SI-2.1a).

Faster degradation has been estimated for total $\alpha-\mathrm{HCH}$ in an Arctic lake ${ }^{61,62}$ and for $\alpha-\mathrm{HCH}$ and $\gamma-\mathrm{HCH}$ in the Greenland Sea ${ }^{63}$ (Table SI-2.7), but the derived rate constants $\left(k_{\mathrm{m}}=0.48-1.13 \mathrm{y}^{-1}\right)$ are too high for LS because they greatly exceed the rate constant for $F_{\text {LOSS }}\left(0.122 \mathrm{y}^{-1}\right.$; Figure 3$)$.

3.3.6. Summary of Removal Processes. $\mathrm{F}_{\text {Loss }}$ and component loss processes (eq 2) are summarized in Table SI-1.2a,b Totals of the annual $\mathrm{F}_{\mathrm{LOSS}}$ give the quantities that dissipated over 30 years, $90400 \mathrm{~kg}$ of $\alpha-\mathrm{HCH}$ and $12200 \mathrm{~kg}$ of $\gamma$-HCH. These measured losses can be compared with estimated losses due to individual processes, Table SI-1.2a,b and Figure 4. As noted in Section 3.3, rate constants for $\mathrm{F}_{\mathrm{VOL}}$, $\mathrm{F}_{\mathrm{HYD}}$, and $\mathrm{F}_{\mathrm{MIC}}$ were applied to the annual GM $\mathrm{C}_{\mathrm{W}}$; thus, their long-term rates are fixed by $\mathrm{F}_{\mathrm{LOSS}}$ and magnitude by the rate constants of the individual processes. The "wavy" line for $\mathrm{F}_{\text {OUT }}$

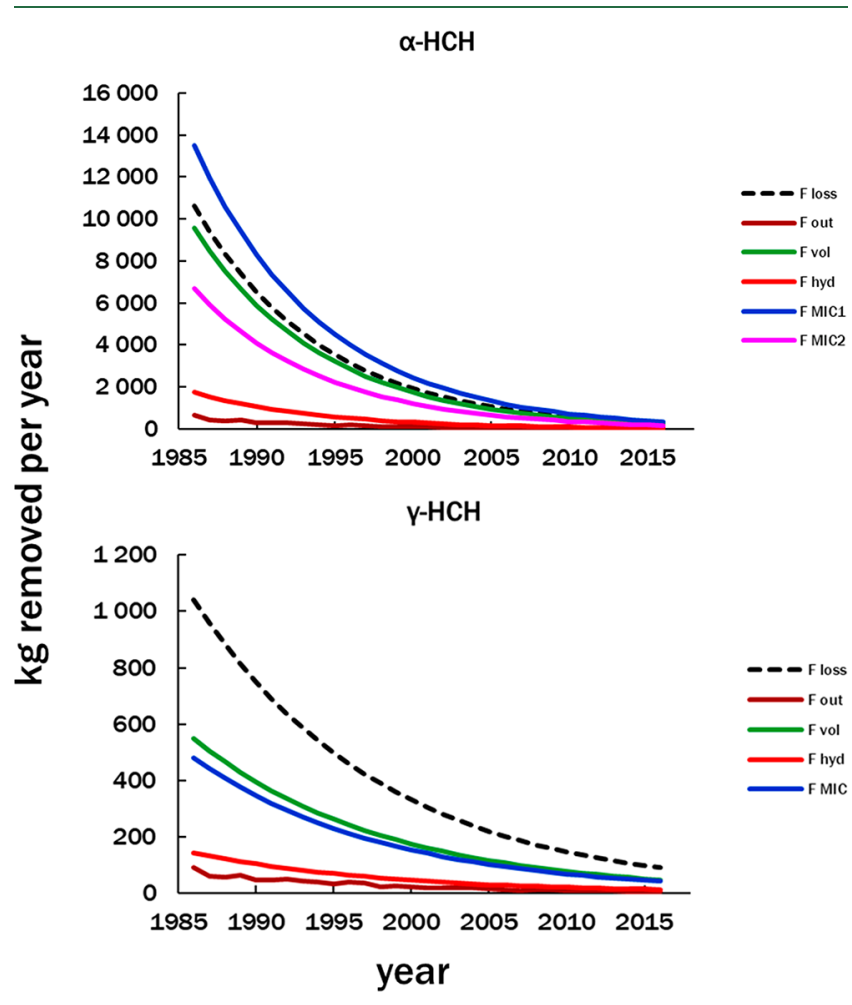

Figure 4. Annual removal flows $\left(\mathrm{F}_{\mathrm{LOSS}}, \mathrm{kg} \mathrm{y}^{-1}\right)$ of $\mathrm{HCHs}$ over 30 years. $\mathrm{F}_{\mathrm{LOSS}}$ is the decline of $\mathrm{HCHs}$ in the lake based on monitoring data (Figure 3). Other flows are estimated by applying process parameters to the declining annual concentrations: volatilization $\left(\mathrm{F}_{\mathrm{VOL}}\right)$, outflow $\left(\mathrm{F}_{\mathrm{OUT}}\right)$, hydrolysis $\left(\mathrm{F}_{\mathrm{HYD}}\right)$, and microbial degradation $\left(\mathrm{F}_{\mathrm{MIC}}\right)$. See corresponding sections here and in SI-2. The wavy lines for $\mathrm{F}_{\mathrm{OUT}}$ are because calculations used annual discharges from the St. Mary's river, which varied from year to year (Table SI-2.4). $\mathrm{F}_{\text {MIC }}$ for $\gamma$ $\mathrm{HCH}$ was estimated using the first-order microbial degradation rate constant reported in the Bering Sea - Eastern Arctic Ocean $\left(k_{\mathrm{m}}=\right.$ $\left.0.037 \mathrm{y}^{-1}\right) .^{32,33}$ Two degradation rate constants were applied for total $\alpha$ - $\mathrm{HCH}$ (both enantiomers); ${ }^{32,33} \mathrm{~F}_{\mathrm{MIC1}}$ used $k_{\mathrm{m}}=0.147 \mathrm{y}^{-1}$ and $\mathrm{F}_{\mathrm{MIC} 2}$ used $k_{\mathrm{m}}=0.070 \mathrm{y}^{-1}$, which was derived by considering the relative degradation rates of the two enantiomers in LS (SI-2, Figure SI-1.4, Table SI-2.7). in Figure 4 is because calculations used annual discharges from the St. Mary's River, which varied from year to year. For $\gamma$ $\mathrm{HCH}$, Process Sum $1\left(\mathrm{~F}_{\mathrm{VOL}}+\mathrm{F}_{\mathrm{OUT}}+\mathrm{F}_{\mathrm{HYD}}\right)=8920 \mathrm{~kg}$ or $73.2 \%$ of total $\mathrm{F}_{\mathrm{LOSS}}$. The inclusion of microbial degradation $\left(\mathrm{F}_{\mathrm{MIC}}\right)$ brings Process Sum $2\left(\mathrm{~F}_{\mathrm{VOL}}+\mathrm{F}_{\mathrm{OUT}}+\mathrm{F}_{\mathrm{HYD}}+\mathrm{F}_{\mathrm{MIC}}\right)$ to $14500 \mathrm{~kg}$, which is $119 \%$ of total $F_{\text {LOss. }}$. Thus, the process sums agree with the measured dissipation within about $20 \%$.

The agreement is less satisfactory for $\alpha-\mathrm{HCH}$. Process Sum $1\left(\mathrm{~F}_{\mathrm{VOL}}+\mathrm{F}_{\mathrm{OUT}}+\mathrm{F}_{\mathrm{HYD}}\right)=101000 \mathrm{~kg}$, or $112 \%$ of total measured $F_{\text {LOss }}, 90400 \mathrm{~kg}$, which would be good agreement except that it does not account for microbial degradation. Adding $\mathrm{F}_{\mathrm{MIC1}}$ raises Process Sum $2\left(\mathrm{~F}_{\mathrm{VOL}}+\mathrm{F}_{\mathrm{OUT}}+\mathrm{F}_{\mathrm{HYD}}+\right.$ $\mathrm{F}_{\mathrm{MIC} 1}$ ) to $239 \%$ of total $\mathrm{F}_{\mathrm{LOSS}}$. Replacing $\mathrm{F}_{\mathrm{MIC} 1}$ with $\mathrm{F}_{\mathrm{MIC} 2}$, which uses a lower rate constant, results in Process Sum 3 $\left(\mathrm{F}_{\mathrm{VOL}}+\mathrm{F}_{\mathrm{OUT}}+\mathrm{F}_{\mathrm{HYD}}+\mathrm{F}_{\mathrm{MIC} 2}\right)=174 \%$ of total $\mathrm{F}_{\mathrm{LOSS}}$. The comparisons of processes with $\mathrm{F}_{\text {LOSS }}$ are displayed in Figure 4.

Uncertainties in the loss budgets are discussed in SI-2.7. The $95 \%$ confidence intervals ${ }^{5}$ (CI) for $\mathrm{k}_{\text {DISS }}$ were derived from the standard error (SE) by $\mathrm{t}_{0.05, \mathrm{n}-2} * \mathrm{SE}$ and are reported in Table 2 of the main paper. Corresponding halving times, calculated from $t_{1 / 2}=0.693 / \mathrm{k}_{\mathrm{DISS}}$, and their uncertainties $(95 \% \mathrm{CI})$ are also reported in Table 2 . The $95 \%$ CI limits range from $83 \%$ to $126 \%$ of the central $t_{1 / 2}$ value (Water $1,1986-2016 \mathrm{GM}$ concentrations) for $\alpha-\mathrm{HCH}$ and $89 \%$ to $114 \%$ of the central $t_{1 / 2}$ value for $\gamma-\mathrm{HCH}$.

Relative uncertainties in $\mathrm{F}_{\mathrm{OUT}}$ and $\mathrm{F}_{\mathrm{HYD}}$ are small, $12 \%$ and $16 \%$, respectively. Sedimentation has high uncertainty due to lack of data concerning sediment concentrations and high variability in sedimentation rates (Table SI-2.5); but even using a high sedimentation rate gives a predicted $\mathrm{F}_{\mathrm{SED}}$ that is negligible compared to other processes. Due to uncertainties in the Whitman two-film model and estimation of $\mathrm{K}_{\mathrm{OL}}$, the relative error in $\mathrm{F}_{\mathrm{VOL}}$ could be in the range 50-130\% (SI-2.7). Enantioselective degradation of $\alpha-\mathrm{HCH}$ (Figure SI-1.4) is a clear indication of microbial degradation, but large uncertainty in the rate constants (Table SI-2.7) makes this process difficult to quantify.

$\mathrm{F}_{\text {LOSS }}$ sets an upper boundary for the individual process rates. The fact that $\mathrm{F}_{\mathrm{MIC1}}$ exceeds $\mathrm{F}_{\mathrm{LOSS}}$ for $\alpha-\mathrm{HCH}$ indicates that the $k_{\mathrm{m}}$ derived from ocean data is too high (SI-2). Process Sum $3\left(\mathrm{~F}_{\mathrm{VOL}}+\mathrm{F}_{\mathrm{OUT}}+\mathrm{F}_{\mathrm{HYD}}+\mathrm{F}_{\mathrm{MIC} 2}\right)$ is $174 \%$ of $\mathrm{F}_{\mathrm{LOSS}}$, and it is likely that $\mathrm{F}_{\mathrm{MIC} 2}$ and/or $\mathrm{F}_{\mathrm{VOL}}$ are overestimated. Because of such limitations, it is better to consider the relative magnitude of removal processes rather than their absolute magnitudes. These are $\mathrm{F}_{\mathrm{VOL}} \approx \mathrm{F}_{\mathrm{MIC}}>\mathrm{F}_{\mathrm{HYD}}>\mathrm{F}_{\mathrm{OUT}}>\mathrm{F}_{\mathrm{SED}}$.

Another long-term data set for $\mathrm{HCHs}$ in a water body is a 40-year record from the Arkona Basin of the Baltic Sea, where total HCHs declined from $12.5 \mathrm{ng} \mathrm{L}^{-1}$ in 1975 to $<0.4 \mathrm{ng} \mathrm{L}^{-1}$ in $2015 .^{64}$ Like LS, inputs to the Baltic were largely atmospheric and the decline over 40 years was due to reduction in air concentrations and dissipation processes. Degradation in the Baltic was estimated at two deep-water stations, where a salinity gradient isolates the water from atmospheric exchange. The halving times calculated from observed losses in deep water ranged from 4.7 to 4.9 y for $\alpha$ $\mathrm{HCH}, 3.9$ to 4.2 y for $\gamma-\mathrm{HCH}$, and 7.2 to 13.6 y for $\beta-\mathrm{HCH}$. The isomer proportion has changed from $\alpha-\mathrm{HCH}>\gamma-\mathrm{HCH}$ in the 1970 s to dominance of $\beta-\mathrm{HCH}$ (measured since 2000) in recent years.

$\mathrm{HCH}$ have declined significantly in the air, water, and fish of LS, a tribute to the success of regulatory controls. It is interesting that the long-term record of $\gamma-\mathrm{HCH}$ in water (Figure 3) shows no irregularities following the lindane phase- 
out in the U.S. and Canada in the 2000s decade or following the Stockholm Convention ban in 2009. It may be that the near-decade response time for LS water and the low frequency of sampling smooth any "blips" that might have occurred. The discrepancies between the directly measured $F_{\text {LOSS }}$ and the sum of loss processes highlights the difficulties in obtaining mass balances based on predictions. Long-term monitoring data are sparse for Great Lakes water. Carlson et al. ${ }^{7}$ stated, "As concentrations in fish reflect concentrations in water, the change in source functions could be the primary factor behind rate changes observed in fish."

\section{ASSOCIATED CONTENT}

\section{SI Supporting Information}

The Supporting Information is available free of charge at https://pubs.acs.org/doi/10.1021/acs.est.0c07549.

Collection, analytical methods, and $\mathrm{HCH}$ concentrations determined by different research teams; total measured dissipation of $\alpha-\mathrm{HCH}$ and $\gamma-\mathrm{HCH}$ from 1986 to 2016; process parameters and estimated losses by volatilization, outflow, sedimentation, hydrolysis and microbial degradation; water concentrations used to estimate volatilization loss in this study and earlier reports; calculation of volatilization mass transfer coefficients; estimation of uncertainties; map of LS with surveillance stations; regressions of the natural logarithms of $\mathrm{C}_{\mathrm{W}} / \mathrm{ng}$ $\mathrm{L}^{-1}$ (annual AM, annual GM and all points) vs year; enantiomer fractions (EFs) of $\alpha-\mathrm{HCH}$ (PDF)

\section{AUTHOR INFORMATION}

\section{Corresponding Author}

Terry F. Bidleman - Department of Chemistry, Umeå University, Umeå SE-90187, Sweden; (1) orcid.org/00000001-7469-0532; Email: terry.bidleman@umu.se

\section{Authors}

Sean Backus - Great Lakes Ecosystem Management Section, Environment and Climate Change Canada, Burlington, Ontario L7R 4A6, Canada

Alice Dove - Water Quality Monitoring and Surveillance Division, Environment and Climate Change Canada, Burlington, Ontario L7R 4A6, Canada

Rainer Lohmann - Graduate School of Oceanography, University of Rhode Island, Narragansett, Rhode Island 02882, United States; 이이이.org/0000-0001-8796-3229

Derek Muir - Aquatic Contaminants Research Division, Environment and Climate Change Canada, Burlington, Ontario L7R 4A6, Canada

Camilla Teixeira - Aquatic Contaminants Research Division, Environment and Climate Change Canada, Burlington, Ontario L7R 4A6, Canada

Liisa Jantunen - Air Quality Processes Research Section, Environment and Climate Change Canada, Egbert, Ontario LOL 1NO, Canada; (1) orcid.org/0000-0003-0261-9539

Complete contact information is available at:

https://pubs.acs.org/10.1021/acs.est.0c07549

\section{Notes}

The authors declare no competing financial interest.

\section{ACKNOWLEDGMENTS}

We thank the officers and crew of the Canadian Coast Guard Ship Limnos, the technical operations team, namely Steve Smith, Todd Breedon, Tina Mamone, and Dave Gilroy. We thank Janine Wideman, Paul Helm, Andi Leone, Céline Audette, Colin Darling, Sonya Wrigglesworth, Anya Gawor, and Jasmine Waltho for help during sampling and/or laboratory support.

\section{REFERENCES}

(1) Eisenreich, S. J.; Looney, B. B.; Thornton, J. D. Airborne organic contaminants in the Great Lakes ecosystem. Environ. Sci. Technol. 1981, 15, 30-38.

(2) Hoff, R. M.; Strachan, W. M. J.; Sweet, C. W.; Chan, C. H.; Shackleton, M.; Bidleman, T. F.; Brice, K. A.; Burniston, D. A.; Cussion, S.; Gatz, D.; Schroeder, W. H. Atmospheric deposition of toxic chemicals to the Great Lakes: review of data through 1994. Atmos. Environ. 1996, 30, 3505-3527.

(3) Swackhamer, D. L.; Schottler, S.; Pearson, R. F. Air-water exchange and mass balance of toxaphene in the Great Lakes. Environ. Sci. Technol. 1999, 33, 3864-3872.

(4) Guo, J.; Salamova, A.; Venier, M.; Dryfhout-Clark, H.; Alexandrou, N.; Backus, S.; Bradley, L.; Hung, H.; Hites, R. A. Atmospheric flows of semi-volatile organic pollutants to the Great Lakes estimated by the United States' Integrated Atmospheric Deposition and Canada's Great Lakes Basin Monitoring and Surveillance Networks. J. Great Lakes Res. 2018, 44, 665-677.

(5) Salamova, A.; Venier, M.; Hites, R. A. Revised temporal trends of persistent organic pollutant concentrations in air around the Great Lakes. Environ. Sci. Technol. Lett. 2015, 2, 20-25.

(6) Shunthirasingham, C.; Gawor, A.; Hung, H.; Brice, K. A.; Su, K.; Alexandrou, N.; Dryfhout-Clark, H.; Backus, S.; Sverko, E.; Shin, C.; Park, R.; Noronha, R. Atmospheric concentrations and loadings of organochlorine pesticides and polychlorinated biphenyls in the Canadian Great Lakes Basin (GLB): Spatial and temporal analysis (1992-2012). Environ. Pollut. 2016, 217, 124-133.

(7) Carlson, D. L.; DeVault, D. S.; Swackhamer, D. L. On the rate of decline of persistent organic contaminants in lake trout (Salvelinus namaycush) from the Great Lakes, 1970-2003. Environ. Sci. Technol. 2010, 44, 2004-2010.

(8) Hites, R. A.; Holsen, T. M. Temporal trends of PCBs and DDTs in Great Lakes fish compared to those in air. Sci. Total Environ. 2019, 646, 1413-1418.

(9) Salamova, A.; Pagano, J. J.; Holsen, T. M.; Hites, R. A. Post-1990 temporal trends of PCBs and organochlorine pesticides in the atmosphere and in fish from lakes Erie, Michigan, and Superior. Environ. Sci. Technol. 2013, 47, 9109-9114.

(10) GLA, 1995. Government of Canada and United States Environmental Protection Agency Great Lakes: An Environmental Atlas and Resource Book. ISBN 0-662-23441-3.

(11) Hornbuckle, K. C.; Jeremlason, J. D.; Sweet, C. W.; Elsenreich, S. J. Seasonal variations in air-water exchange of polychlorinated biphenyls in Lake Superior. Environ. Sci. Technol. 1994, 28, 14911501.

(12) Jeremiason, J. D.; Hornbuckle, K. C.; Eisenreich, S. J. PCBs in Lake Superior, 1978-1992. Decrease in water concentrations reflect loss by volatilization. Environ. Sci. Technol. 1994, 28, 903-914.

(13) James, R. R.; McDonald, J. G.; Symonik, D. M.; Swackhamer, D.; Hites, R. A. Volatilization of toxaphene from lakes Michigan and Superior. Environ. Sci. Technol. 2001, 35, 3653-3660.

(14) Vijgen, J.; Abhilash, P. C.; Li, Y. F.; Lal, R.; Forter, M.; Torres, J.; Singh, N.; Yunus, M.; Tian, C.; Schäffer, A.; Weber, R. Hexachlorocyclohexane $(\mathrm{HCH})$ as new Stockholm Convention POPs - a global perspective on the management of lindane and its waste isomers. Environ. Sci. Pollut. Res. 2011, 18, 152-162.

(15) Walker, K.; Vallero, D. A.; Lewis, R. G. Factors influencing the distribution of lindane and other hexachlorocyclohexanes in the environment. Environ. Sci. Technol. 1999, 33, 4373-4378. 
(16) Willett, K. L.; Ulrich, E. M.; Hites, R. A. Differential toxicity and environmental fates of hexachlorocyclohexane isomers. Environ. Sci. Technol. 1998, 32, 2197-2207.

(17) Li, Y. F.; Macdonald, R. W. Sources and pathways of selected organochlorine pesticides to the Arctic and the effect of pathway divergence on $\mathrm{HCH}$ trends in biota: a review. Sci. Total Environ. 2005, 342, 87-106.

(18) Breivik, K.; Pacyna, J. M.; Münch, J. Use of $\alpha$-, $\beta$-, and $\beta$ hexachlorocyclohexane in Europe, 1970-1996. Sci. Total Environ. 1999, 239, 151-163.

(19) Becker, S.; Halsall, C. J.; Tych, W.; Kallenborn, R.; Su, Y.; Hung, $\mathrm{H}$. Long-term trends in atmospheric concentrations of $\alpha$ - and $\beta-\mathrm{HCH}$ in the Arctic provide insight into the effects of legislation and climatic fluctuations on contaminant levels. Atmos. Environ. 2008, 42, $8225-8233$.

(20) Li, Y. F.; Struger, J.; Waite, D.; Ma, J. Gridded Canadian lindane usage inventories with $1 / 6^{\circ} \times 1 / 4^{\circ}$ latitude and longitude resolution. Atmos. Environ. 2004, 38, 1117-1124.

(21) O’Reilly, J.; Yarto, M. North American Regional Action Plan on Lindane and other Hexachlorocyclohexane Isomers: Final Evaluation Report. Commission for Environmental Cooperation, Montreal, Montreal, Canada, 45 pp., 2013.

(22) Jantunen, L. M.; Bidleman, T. F. Air-water gas exchange of toxaphene in Lake Superior. Environ. Toxicol. Chem. 1993, 22, 12291237.

(23) Muir, D. C. G.; Swackhamer, D. L.; Bidleman, T. F.; Jantunen, L. M. Toxaphene in the Great Lakes Handbook of Environmental Chemistry, Vol. 5, , Springer-Verlag: Berlin Heidelberg, 2005.

(24) Jantunen, L. M.; Helm, P. A.; Ridal, J. J.; Bidleman, T. F. Airwater gas exchange of chiral and achiral organochlorine pesticides in the Great Lakes. Atmos. Environ. 2008, 42, 8533-8542.

(25) Venier, M.; Dove, A.; Romanak, K.; Backus, S.; Hites, R. Flame retardants and legacy chemicals in Great Lakes' water. Environ. Sci. Technol. 2014, 48, 9563-9572.

(26) Williams, D. J.; Kuntz, K. W.; L'Italien, S.; Richardson, V. Organic contaminants in the Great Lakes 1992-1998. Intra- and inter-lake spatial distributions and temporal trends. Ecosystem Health Division, Environmental Conservation Branch, Ontario Region, Burlington, Ontario, Report No. EHD/ECB-OR/01-01/I, 2001.

(27) Ruge, Z.; Muir, D.; Helm, P.; Lohmann, R. Concentrations, trends, and air-water exchange of $\mathrm{PCBs}$ and organochlorine pesticides derived from passive samplers in Lake Superior in 2011. Environ. Sci. Technol. 2018, 52, 14061-14069.

(28) McConnell, L. L.; Cotham, W. E.; Bidleman, T. F. Gas exchange of hexachlorocyclohexanes in the Great Lakes. Environ. Sci. Technol. 1993, 27, 1304-1311.

(29) Xiao, H.; Li, N.; Wania, F. Compilation, evaluation, and selection of physical-chemical property data for $\alpha$-, $\beta$-, and $\beta$ hexachlorocyclohexane. J. Chem. Eng. Data 2004, 49, 173-185.

(30) Shen, L.; Wania, F.; Lei, Y. D.; Teixeira, C.; Muir, D. C. G.; Bidleman, T. F. Hexachlorocyclohexanes in the North American atmosphere. Environ. Sci. Technol. 2004, 38, 965-975.

(31) Harner, T.; Wiberg, K.; Norstrom, R. Enantiomer fractions are preferred to enantiomer ratios for describing chiral signatures in environmental analysis. Environ. Sci. Technol. 2000, 34, 218-220.

(32) Harner, T.; Kylin, H.; Bidleman, T. F.; Strachan, W. M. J. Removal of $\alpha$ - and $\gamma$-hexachlorocyclohexanes (HCHs) and enantiomers of $\alpha-\mathrm{HCH}$ in the eastern Arctic Ocean. Environ. Sci. Technol. 1999, 33, 1157-1164.

(33) Harner, T.; Jantunen, L. M.; Bidleman, T. F.; Macdonald, R. W.; Kylin, H.; Strachan, W. M. J. Microbial degradation is a key elimination pathway of hexachlorocyclohexanes from the Arctic Ocean. Geophys. Res. Lett. 2000, 27, 1155-1158.

(34) Jantunen, L. M.; Bidleman, T. F. Air-water gas exchange of $\mathrm{HCH}$ and the enantiomers of $\alpha-\mathrm{HCH}$ in arctic regions. J. Geophys. Res. 1996, 101, 28837-28846.

(35) Jantunen, L. M.; Bidleman, T. F. Corrections to: Air-water gas exchange of $\mathrm{HCHs}$ and the enantiomers of $\alpha-\mathrm{HCH}$ in arctic regions. J. Geophys. Res. 1997, 102, 19279-19282.
(36) Pućko, M.; Macdonald, R. W.; Barber, D. G.; Rosenberg, B.; Gratton, Y.; Stern, G. A. Alpha-HCH enantiomer fraction (EF): A novel approach to calculate the ventilation age of water in the Arctic Ocean? J. Geophys. Res. Oceans 2012, 117, C08038.

(37) Ridal, J. J.; Bidleman, T. F.; Kerman, B.; Fox, M. E.; Strachan, W. M. J. Enantiomers of $\alpha$-hexachlorocyclohexane as tracers of airwater gas exchange in Lake Ontario. Environ. Sci. Technol. 1997, 31, $1940-1945$

(38) Jantunen, L. M.; Helm, P. A.; Kylin, H.; Bidleman, T. F. Hexachlorocyclohexanes $(\mathrm{HCHs})$ in the Canadian Archipelago. 2. Air-water gas exchange of $\alpha$ - and $\beta$-HCHs. Environ. Sci. Technol. 2008, 42, 465-470.

(39) CEPA, 2018. Virtual elimination plans. Canadian Environmental Protection Act of 1999 (accessed Nov. 1, 2020). https://www. canada.ca/en/environment-climate-change/services/canadianenvironmental-protection-act-registry/plans-policies/virtualelimination.html.

(40) Hites, R. A.; Lehman, D. C.; Salamova, A.; Venier, M. Temporal environmental hysteresis: A definition and implications for polybrominated diphenyl ethers. Sci. Total Environ. 2021, 753, 141849.

(41) Galarneau, E.; Audette, C. V.; Bandemehr, A.; Basu, I.; Bidleman, T. F.; Brice, K. A.; Burniston, D. A.; Chan, C. H.; Froude, F.; Hites, R. A.; Hulting, M. L.; Neilson, M.; Orr, D.; Simcik, M. F.; Strachan, W. M. J.; Hoff, R. M. Atmospheric deposition of toxic substances to the Great Lakes: IADN results to 1996. Environment Canada and the United States Environmental Protection Agency, Public Works and Government Services Canada Catalogue Number: En56156/2000E-IN, US EPA Report Number: EPA 905-R-00004, ISBN: 0662-29005-4.

(42) Baker, J. E.; Eisenreich, S. J.; Johnson, T.C.; Halfman, B. M. Chlorinated hydrocarbon cycling in the benthic nepheloid layer of Lake Superior. Environ. Sci. Technol. 1985, 19, 854-861.

(43) Baker, J. E.; Capel, P. D.; Eisenreich, S. J. Influence of colloids on sediment-water partition coefficients of polychlorobiphenyl congeners in natural waters. Environ. Sci. Technol. 1986, 20, 11361143.

(44) Baker, J. E.; Eisenreich, S. J.; Eadie, B. J. Sediment trap fluxes and benthic recycling of organic carbon, polycyclic aromatic hydrocarbons, and polychlorobiphenyl congeners in Lake Superior. Environ. Sci. Technol. 1991, 25, 500-509.

(45) Jeremiason, J. D.; Eisenreich, S. J.; Baker, J. E.; Eadie, B. J. PCB decline in settling particles and benthic recycling of PCBs and PAHs in Lake Superior. Environ. Sci. Technol. 1998, 32, 3249-3256.

(46) Ngabe, N.; Bidleman, T. F.; Falconer, R. L. Base hydrolysis of $\alpha$ - and $\gamma$-hexachlorocyclohexanes. Environ. Sci. Technol. 1993, 27, $1930-1933$

(47) Law, S. A.; Diamond, M. L.; Helm, P. A.; Jantunen, L. M.; Alaee, M. Factors affecting the occurrence and enantiomeric degradation of hexachlorocyclohexane isomers in northern and temperate aquatic systems. Environ. Toxicol. Chem. 2001, 20, 26902698.

(48) Law, S. A.; Bidleman, T. F.; Martin, M. J.; Ruby, M. V. Evidence of enantioselective degradation of $\alpha$-hexachlorocyclohexane in groundwater. Environ. Sci. Technol. 2004, 38, 1634-1638.

(49) Nagata, Y.; Endo, R.; Ito, M.; Ohtsubo, Y.; Tsuda, M. Aerobic degradation of lindane ( $\gamma$-hexachlorocyclohexane) in bacteria and its biochemical and molecular basis. Appl. Microbiol. Biotechnol. 2007, 76, $741-752$.

(50) Raina, V.; Hauser, A.; Buser, H. R.; Rentsch, D.; Sharma, P.; Lal, R.; Holliger, C.; Poiger, T.; Müller, M. D.; Kohler, H. P. Hydroxylated metabolites of $\beta$-and $\delta$-hexachlorocyclohexane: bacterial formation, stereochemical configuration, and occurrence in groundwater at a former production site. Environ. Sci. Technol. 2007, 41, $4292-4298$

(51) Geueke, B.; Garg, N.; Ghosh, S.; Fleischmann, T.; Holliger, C.; Lal, R.; Kohler, H. P. E. Metabolomics of hexachlorocyclohexane $(\mathrm{HCH})$ transformation: ratio of $\operatorname{LinA}$ to $\operatorname{LinB}$ determines metabolic fate of HCH isomers. Environ. Microbiol. 2013, 15, 1040-1049. 
(52) Liu, Y.; Wu, L.; Kohli, P.; Kumar, R.; Stryhanyuk, H.; Nijenhuis, I.; Lal, R.; Richnow, H. H. Enantiomer and carbon isotope fractionation of $\alpha$-hexachlorocyclohexane by Sphingobium indicum strain $\mathrm{B} 90 \mathrm{~A}$ and the corresponding enzymes. Environ. Sci. Technol. 2019, 53, 8715-8724.

(53) Verma, H.; Kumar, R.; Oldach, P.; Sangwan, N.; Khurana, J. P; Gilbert, J. A; Lal, R. Comparative genomic analysis of nine Sphingobium strains: insights into their evolution and hexachlorocyclohexane $(\mathrm{HCH})$ degradation pathways. BMC Genomics 2014, 15, 1014.

(54) Lodha, B.; Bhat, P.; Kumar, M. S.; Vaidya, A. N.; Mudliar, S.; Killedar, D. J.; Chakrabarti, T. Bioisomerization kinetics of $\alpha-\mathrm{HCH}$ and biokinetics of Pseudomonas aeruginosa degrading technical $\mathrm{HCH}$. Biochem. Eng. J. 2007, 35, 12-19.

(55) Phillips, T. M.; Seech, A. G.; Lee, H.; Trevors, J. T. Biodegradation of hexachlorocyclohexane $(\mathrm{HCH})$ by microorganisms. Biodegradation 2005, 16, 363-392.

(56) Nagata, Y.; Kato, H.; Ohtsubo, Y.; Tsuda, M. Minireview: lessons from the genomes of lindane-degrading sphingomonads. Environ. Microbiol. Rep. 2019, 11, 630-644.

(57) Schilling, I. E.; Hess, R.; Bolotin, J.; Lal, R.; Hofstetter, T. B.; Kohler, H.-P. E. Kinetic isotope effects of the enzymatic transformation of $\beta$-hexachlorocyclohexane by the lindane dehydrochlorinase variants LinA1 and LinA2. Environ. Sci. Technol. 2019, 53, $2353-2363$.

(58) Suar, M.; Hauser, A.; Poiger, T.; Buser, H. R.; Müller, M. D.; Dogra, C.; Raina, V.; Holliger, C.; van der Meer, J. R.; Lal, R.; Kohler, H. P. E. Enantioselective transformation of $\alpha$-hexachlorocyclohexane by the dehydrochlorinases LinA1 and LinA 2 from the soil.

(59) Bidleman, T. F.; Jantunen, L. M.; Kurt-Karakus, P. B.; Wong, F. Chiral compounds as tracers of atmospheric sources and fate: review and prospects for investigating climate change influences. Atmos. Pollut. Res. 2012, 3, 371-382.

(60) Lu, Q.; Qiu, L.; Yu, L.; Zhang, S.; Alves de Toledo, R.; Shim, H.; Wang, S. Microbial transformation of chiral organohalides: Distribution, microorganisms and mechanisms. J. Hazard. Mater. 2019, 368, 849-861.

(61) Helm, P. A.; Diamond, M. L.; Semkin, R.; Bidleman, T. F. Degradation as a loss mechanism in the fate of $\alpha$-hexachlorocyclohexane in arctic wetlands. Environ. Sci. Technol. 2000, 34, 812-818.

(62) Helm, P. A.; Diamond, M. L.; Semkin, R.; Strachan, W. M. J.; Teixeira, C.; Gregor, D. A mass balance model describing multiyear fate of organochlorine compounds in a high Arctic lake. Environ. Sci. Technol. 2002, 36, 996-1003.

(63) Galbán-Malagón, C. J.; Berrojalbiz, N.; Gioia, R.; Dachs, J. The "degradative" and "biological" pumps controls on the atmospheric deposition and sequestration of hexachlorocyclohexanes and hexachlorobenzene in the North Atlantic and Arctic oceans. Environ. Sci. Technol. 2013, 47, 7195-7203.

(64) Abraham, M.; Theobald, N.; Schulz-Bull, D. Hexachlorocyclohexane - Long term variability and spatial distribution in the Baltic Sea. Chemosphere 2017, 168, 1356-1364. 